\title{
Novel protective role of curcumin and taurine combination against experimental hepatocarcinogenesis
}

\author{
MOTAWA EISA EL-HOUSEINI $^{1,2}$, IBRAHIM ALI EL-AGOZA ${ }^{3}$, \\ MONA MOHAMED SAKR ${ }^{1,2}$ and GHADA MOHAMED EL-MALKY ${ }^{3}$
}

Departments of ${ }^{1}$ Tumor Biology and ${ }^{2}$ Pathology, National Cancer Institute, Cairo University, Cairo 11796; ${ }^{3}$ Department of Zoology, Faculty of Science, Cairo University, Giza 12613, Egypt

Received September 15, 2015; Accepted July 22, 2016

DOI: $10.3892 / \mathrm{etm} .2016 .3952$

\begin{abstract}
Hepatocarcinogenesis is a prerequisite to hepatocellular carcinoma (HCC), which is one of the most common cancers among humans. Therefore, it is important to search for agents that protect against hepatocarcinogenesis. The present study aimed to investigate the protective effects of a combination of taurine and curcumin against experimental hepatocarcinogenesis induced by diethyl nitrosamine (DENA) in a rat model. A total of 100 rats were divided into eight groups. Eight weeks following DENA injection and treatment with curcumin and taurine, the rats were sacrificed to obtain blood and hepatic tissue samples for the evaluation of various markers and histopathological observations. Serum levels of interleukin-2 (IL-2), interferon- $\gamma$ (IFN- $\gamma$ ), $\alpha$-fetoprotein (AFP) and $\alpha$-L-fucosidase (AFU) were determined. Rats injected with DENA for eight weeks showed a high percentage of malignant changes in hepatic tissues, as well as a significant increases in the serum levels of AFP and AFU and significant reductions in the serum levels of IL-2 and IFN- $\gamma$. Treatment with curcumin and taurine markedly reduced the extent of malignant changes in the rat liver tissues, with their liver tissues showing patterns similar to that of the normal control rats. In addition, this combination resulted in normal serum levels of IL- 2 , IFN- $\gamma$, AFP and AFU. The results of the present study suggested that a combination of curcumin and taurine may be a novel prophylactic agent against hepatocarcinogenesis in high-risk groups exposed to chemical hepatocarcinogens.
\end{abstract}

Correspondence to: Professor Motawa Eisa El-Houseini, Department of Tumor Biology, National Cancer Institute, Cairo University, 1 Al Kasr Al Eini Street, Fom El Khalig, Cairo 11796, Egypt

E-mail: motawa_matter@yahoo.com

Key words: rat hepatocarcinogenesis, curcumin, taurine, interleukin-2, interferon- $\gamma, \alpha$-fetoprotein, $\alpha$-L-fucosidase

\section{Introduction}

It has previously been demonstrated that treatment of rats with diethylnitroseamine (DENA) induced moderate and well-differentiated forms of hepatocellular carcinoma (HCC) that resembled human HCC (1) HCC is the second most common cause of cancer-associated mortality in males and the sixth among females (2). In previous studies, a diet rich in dietary antioxidants and phytochemicals was shown to decrease the risk of HCC (3-5). Therefore, identifying potential chemopreventive agents in the human diet, and their underlying molecular mechanisms, has been considered the best strategy for protecting against human hepatocarcinogenesis (3). Numerous investigators have attempted to use naturally occurring compounds for preventing or inhibiting carcinogenesis (6-10). Furthermore, various natural bioactive compounds have been shown to exert anti-cancer effects, including reversing the epigenetic mechanisms underlying cancer, reducing tumorigenesis and metastasis, and targeting cancer stem cells (11).

Previous studies have demonstrated that taurine, which is an amino-acid derivative, exhibits a protective effect against oxidation-induced cellular stress by acting as a free radical scavenger in various cells and tissues (12-15). In addition, taurine has been shown to exert hepatoprotective effects, including inhibiting the accumulation of extracellular matrix components in an experimental model of liver fibrosis $(16,17)$. Furthermore, it was shown to protect against genotoxicity induced by anti-neoplastic drugs in somatic and germ tissues, and may be of therapeutic potential in alleviating the risk of secondary tumors following chemotherapy $(18,19)$. Taurine also reduced lipid peroxidation and the levels of proinflammatory cytokines in a rat model of acute pancreatitis by increasing the levels of superoxide dismutase and glutathione peroxidase (20). In addition, taurine has been shown to exert an anti-cancer effect by inducing the apoptosis of cancer cells, although the underlying molecular mechanism of this effect is not well understood (21).

In a previous study, p53-upregulated modulator of apoptosis (PUMA) was shown to respond to taurine treatment in human colorectal cancer cells, which may be useful in the targeted therapy of p53-deficient colorectal cancer (22). Furthermore, it has been demonstrated that silencing the 
PUMA gene with specific small interfering RNA (siRNA) was able to significantly reduce the ability of taurine to inhibit the proliferation and induce the apoptosis of human HCC HepG2 cells (23).

Curcumin (diferuloyl methane), which is a yellow curry pigment obtained from turmeric extract (Curcuma longa), has been shown to be a potent anti-inflammatory, anti-carcinogenic and anti-oxidative agent in a number of pre-clinical trials (24-27). In addition, curcumin was demonstrated to exert chemopreventive effects against DENA-induced murine hepatocarcinogenesis (28). The inhibition of tumor formation by curcumin has been attributed to its anti-initiation and anti-promotional effects. The former effect may result from its ability to inhibit the formation of DNA damage (29-31), whereas the latter may be mediated via anti-proliferation effects or induction of apoptosis in the initiated cells (32-35).

Curcumin has previously been shown to be a potent immunomodulatory agent that can modulate the activation of T-cells, B-cells, macrophages, neutrophils, natural killer cells and dendritic cells (36). Furthermore, curcumin was shown to downregulate the expression of various proinflammatory cytokines, including tumor necrosis factor- $\alpha$ (TNF- $\alpha$ ), interleukin (IL)-1, IL-2, IL-6, IL-8 and IL-12, by inactivation of the transcription factor nuclear factor- $\mathrm{\kappa B}$ (37).

In another study, curcumin and taurine alone or in combination inhibited the growth of leukemic cells propagated in vitro, and increased the level of interferon- $\gamma($ IFN- $\gamma$ ) in the conditioned media of the cells (38). Furthermore, curcumin and taurine treatment resulted in a significant increase in $\mathrm{CD} 25^{+}$mononuclear leukocytes in healthy control and cirrhotic patients, and when propagated in vitro, although the increase was not significant in HCC patients (39).

The present study aimed to investigate the protective effects of a combination of taurine and curcumin in a rat model of DENA-induced hepatocarcinogenesis.

\section{Materials and methods}

Animals. A total of 100 male albino rats, weighing 80-100 g and aged 6-8 weeks, were obtained from the Institute of Ophthalmology (Giza, Egypt). The rats were housed five per cage under optimal conditions of temperature $\left(27-30^{\circ} \mathrm{C}\right)$ and humidity $(40-70 \%)$, and were fed a standard pellet diet and water. The diet consisted of $20 \%$ protein, $5 \%$ fiber, $3.5 \%$ fat and $6.5 \%$ ash, as well as vitamin mixtures. Feed and water were available ad libitum throughout the experimental period. Ethical approval for the present study was granted by the Institutional Animal Care and Use Committee of Cairo University (Cairo, Egypt).

Experimental procedure. A suspension of curcumin in saline was prepared at a concentration of $400 \mathrm{mg} / 40 \mathrm{ml}$, after which $2.5 \mathrm{ml}$ curcumin suspension was orally administered to a rat $(100 \mathrm{mg} / \mathrm{kg}$ body weight). Taurine in saline was prepared at a concentration of $1,000 \mathrm{mg} / 100 \mathrm{ml}$, after which $1 \mathrm{ml}$ taurine solution was administered orally to a rat $(100 \mathrm{mg} / \mathrm{kg}$ body weight).

Rats were divided into eight groups, as follows: i) Control group $(n=10)$, in which the rats were treated with daily intraperitoneal injection of saline parallel for 8 weeks; ii) DENA-injected group $(\mathrm{n}=13)$, in which the rats were intraperitoneally injected with DENA $(100 \mathrm{mg} / \mathrm{kg}$ body weight; Sigma-Aldrich, St. Louis, MO, USA) twice a week for 8 weeks; iii) taurine plus curcumin treated group $(n=10)$, in which the rats were injected into the stomach with taurine $(500 \mathrm{mg} / \mathrm{kg}$ body weight) and curcumin $(100 \mathrm{mg} / \mathrm{kg}$ body weight) daily, with a $1 \mathrm{~h}$ interval between the two injections, for 8 weeks; iv) the taurine, curcumin and DENA treated group $(n=14)$, in which the rats were treated with the same dose of taurine and curcumin for one week prior to DENA injection, and received continued treatment $[1 \mathrm{ml}$ curcumin $(25 \mathrm{mg} / 100 \mathrm{~g}$ body weight) and $2.5 \mathrm{ml}$ taurine $(10 \mathrm{mg} / 100 \mathrm{~g}$ body weight] until the day of sacrifice; $v$ ) the curcumin-treated group $(n=10)$, in which the rats were injected into the stomach with curcumin (100 mg/kg body weight) daily for 8 weeks; vi) the curcumin plus DENA treated group $(n=12)$, in which the rats were treated with the same dose of curcumin for one week prior to DENA injection, and received continued treatment until the day of sacrifice; vii) the taurine-treated group $(\mathrm{n}=10)$, in which the rats were injected into the stomach with taurine $(500 \mathrm{mg} / \mathrm{kg}$ body weight) for 8 weeks; and viii) the taurine plus DENA treated group $(n=12)$, in which the rats were treated with the same dose of taurine for one week prior to DENA injection, and received continued treatment until the day of sacrifice.

Histopathological analysis. After 8 weeks of treatment, the rats were sacrificed via an overdose of $50 \mathrm{mg} / \mathrm{ml}$ ketamine (40 mg/kg; Sigmatech Pharmaceutical Industries, Cairo, Egypt) and sacrificed to obtain liver tissue samples for the detection of HCC. Liver tissue was fixed in $10 \%$ normal saline and buffered neutral formalin for 7 days, after which the tissues were washed and dehydrated in ascending grades of ethyl alcohol, cleared using benzene and embedded in paraffin for $1.5 \mathrm{~h}$ in the oven at $55^{\circ} \mathrm{C}$. Serial sections $(5 \mu \mathrm{m})$ were cut using a microtome and stained with hematoxylin and eosin, as described previously (40). The tissue sections were then analyzed under a light microscope.

Analysis of liver tumor markers. Serum levels of $\alpha$-fetoprotein (AFP) were analyzed using an ELISA kit (ShARa/AFP/FITC; Nordic-MUbio, Susteren, The Netherlands). Serum levels of $\alpha$-L-fucosidase (AFU) were determined using a colorimetric method, according to a previous study (41). Serum levels of the cytokines IL-2 (MBS494288) and IFN- $\gamma$ (RIF00) were determined using ELISA kits from MyBioSource, Inc. (San Diego, CA, USA) and R\&D Systems, Inc. (Minneapolis, MN, USA), respectively.

Electron microscope analysis. The rat livers were removed immediately following sacrifice, and the liver tissue was fixed in $4 \%$ formaldehyde and $1 \%$ gluteraldehyde in $0.1 \mathrm{M}$ phosphate buffer ( $\mathrm{pH}$ 7.4) to prepare for electron microscopy analysis, according to a previous study (42). The liver tissue sections were then analyzed under an electron microscope.

Statistical analysis. Data are presented as the mean \pm standard deviation. Differences among groups and differences between different time points were analyzed using one-way analysis of variance, followed by Newman-Keuls method, where 
Table I. Serum levels of AFP and AFU in rats injected with DENA and treated with curcumin and taurine.

\begin{tabular}{lcrr}
\hline Group & Rats (n) & AFP (ng/ml) & AFU (U/l) \\
\hline Control & 10 & $1.96 \pm 0.67$ & $251.9 \pm 57.44$ \\
DENA & 13 & $18.01 \pm 1.26$ & $669.54 \pm 41.08$ \\
Curcumin & 10 & $0.9 \pm 0.43$ & $299.46 \pm 36.79$ \\
Curcumin + DENA & 12 & $12.28 \pm 0.74$ & $312.4 \pm 39.93$ \\
Taurine & 10 & $1.32 \pm 0.27$ & $295.28 \pm 62.67$ \\
Taurine + DENA & 12 & $7.84 \pm 0.69$ & $296.55 \pm 41.66$ \\
Taurine + curcumin & 10 & $1.53 \pm 0.47$ & $175.54 \pm 30.66$ \\
Taurine + curcumin + DENA & 14 & $7.95 \pm 0.43$ & $271.05 \pm 36.99$ \\
F-value & & & 0.8 \\
$\quad$ Control & & $32.94^{\mathrm{a}}$ & 1.5 \\
Treatments & & $23.18^{\mathrm{a}}$ & \\
\hline
\end{tabular}

The greater the F-value the greater the significance of difference. ${ }^{a} \mathrm{P}<0.001$. AFP, $\alpha$-fetoprotein, AFU, $\alpha$-L-fucosidase; DENA, diethylnitroseamine.

Table II. Serum levels of IL-2 and IFN- $\gamma$ in rats injected with DENA and treated with curcumin and taurine.

\begin{tabular}{lccc}
\hline Group & Rats $(\mathrm{n})$ & $\mathrm{IL}-2(\mathrm{pg} / \mathrm{ml})$ & IFN- $\gamma(\mathrm{pg} / \mathrm{ml})$ \\
\hline Control & 10 & $251.15 \pm 14.39$ & $161.59 \pm 10.28$ \\
DENA & 13 & $29.56 \pm 2.9$ & $16.54 \pm 0.91$ \\
Curcumin & 10 & $229.35 \pm 9.87$ & $209.17 \pm 34.36$ \\
Curcumin + DENA & 12 & $167.66 \pm 13.56$ & $109.44 \pm 4.74$ \\
Taurine & 10 & $203.61 \pm 9.2$ & $181.22 \pm 5.83$ \\
Taurine + DENA & 12 & $173.34 \pm 5.63$ & $102.73 \pm 4.72$ \\
Taurine + curcumin & 10 & $266.81 \pm 12.68$ & $171.32 \pm 8.01$ \\
Taurine + curcumin + DENA & 14 & $191.43 \pm 4.69$ & $122.83 \pm 4.89$ \\
F-value & & & 1.489 \\
$\quad$ Control & & $83.44^{\mathrm{a}}$ & 1.15 \\
Treatments & & & $130.92^{\mathrm{a}}$ \\
\hline
\end{tabular}

The greater the F-value the greater the significance of difference. ${ }^{\mathrm{a}} \mathrm{P}<0.001$. IL-2, interleukin-2; IFN- $\gamma$, interferon- $\gamma$; DENA, diethylnitroseamine

appropriate. $\mathrm{P}<0.05$ was considered to indicate a statistically significant difference.

\section{Results}

Biochemical analysis. The serum levels of AFP and AFU were significantly elevated in the DENA-injected group, as compared with the control group $(\mathrm{P}<0.001)$. Conversely, the serum levels of AFP and AFU were significantly decreased in the groups treated with curcumin and/or taurine $(\mathrm{P}<0.001)$. However, no significant differences were detected in the serum levels of these markers among the curcumin alone, taurine alone and curcumin plus taurine groups $(\mathrm{P}>0.05$; Table I).

Serum levels of IL-2 were significantly decreased in the DENA-injected group, as compared with the control group $(\mathrm{P}<0.001)$. Conversely, the serum levels of IL-2 were significantly elevated in the rats treated with curcumin and/or taurine. Furthermore, the present results demonstrated there

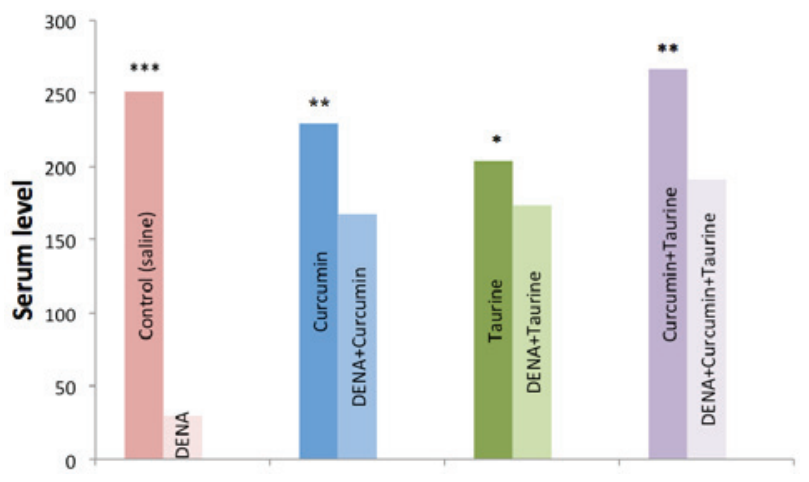

Figure 1. Levels of interleukin-2 in the serum of the control, DENA-injected and taurine- and/or curcumin-treated rats. DENA, diethylnitroseamine. ${ }^{*} \mathrm{P}>0.05 ;{ }^{* * *} \mathrm{P}<0.05 ;{ }^{* * * *} \mathrm{P}<0.001$.

were no significant differences in the serum levels of IL-2 among the curcumin alone, taurine alone and curcumin plus taurine groups (Table II and Fig. 1). 


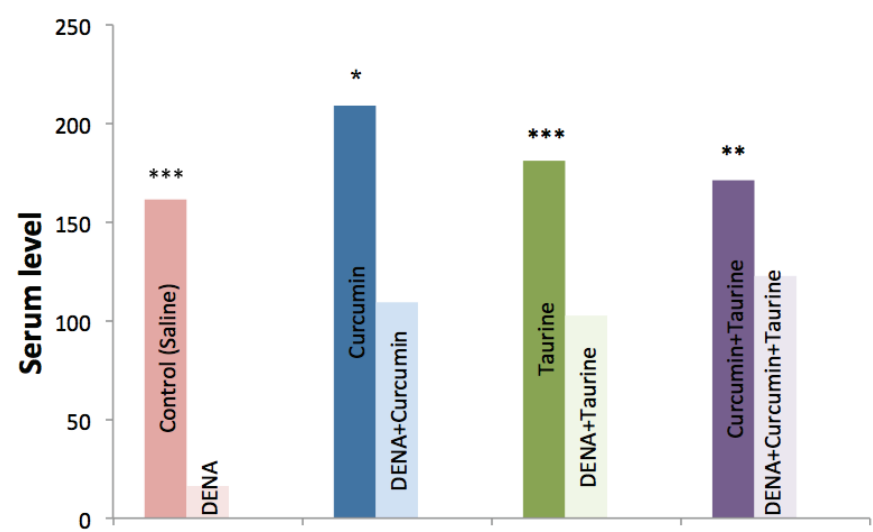

Figure 2. Levels of interferon- $\gamma$ in the serum of the control, DENA-injected and taurine- and/or curcumin-treated rats. DENA, diethylnitroseamine. ${ }^{*} \mathrm{P}>0.05 ;{ }^{* * *} \mathrm{P}<0.05 ;{ }^{* * *} \mathrm{P}<0.001$.

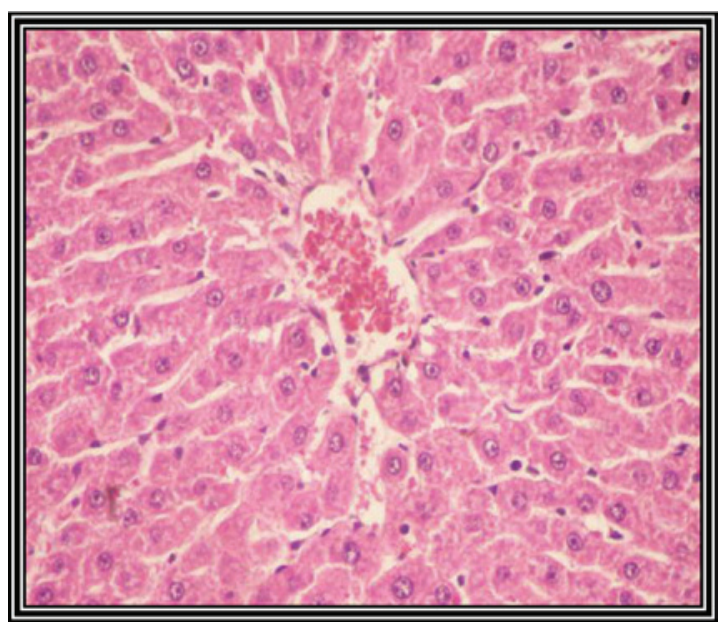

Figure 3. Photomicrograph of a liver section from untreated control rats showing normal organized hepatic tissue with normal hepatocytes (hematoxylin and eosin staining; magnification, $\mathrm{x} 400$ ).

Serum levels of IFN- $\gamma$ were significantly decreased in the DENA-injected group, as compared with the control group $(\mathrm{P}<0.001)$, whereas, the serums level of this cytokine were significantly elevated in the curcumin and/or taurine treated groups $(\mathrm{P}<0.001)$. In addition, there were no significant differences in the serum levels of IFN- $\gamma$ among the curcumin alone, taurine alone and curcumin plus taurine groups ( $\mathrm{P}>0.05$; Table II and Fig. 2).

Pathological observations. Fig. 3 shows a liver tissue section from a control group rat. It shows a normal liver tissue pattern with normal hepatocytes. A histological observation of liver tissue sections from DENA-injected rats at 4 weeks post-injection showed only mild dysplastic changes, with no obvious malignant changes (not shown). However, at 6 weeks following DENA injection, the tissue sections of the liver showed dysplastic changes, including disorganized hepatic cords (not shown), and liver sections at 8 weeks following DENA injection showed malignant changes associated with HCC grade 1, including nuclear hyperchromasia, irregular anaplasia and pleomorphism, with scattered mitotic figures (Fig. 4).

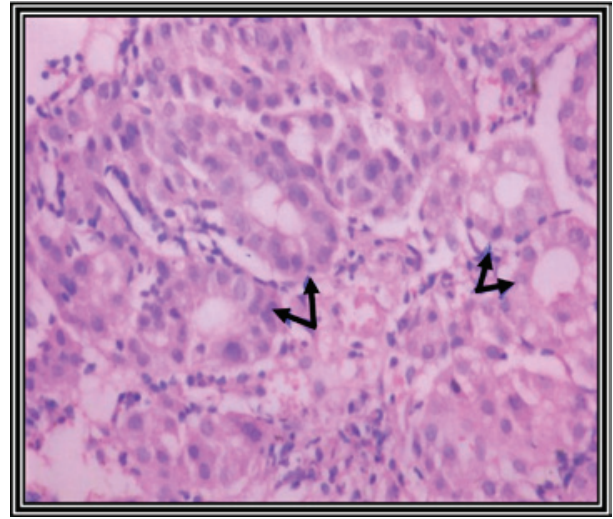

Figure 4. Photomicrograph of a liver section from rats injected with diethylnitroseamine (DENA) for 8 weeks. DENA-injected rats showed malignant hepatocytes arranged in acini, with abundant cytoplasmic vacuolization, as indicative of grade 1 hepatocellular carcinoma (hematoxylin and eosin staining; magnification, x120).

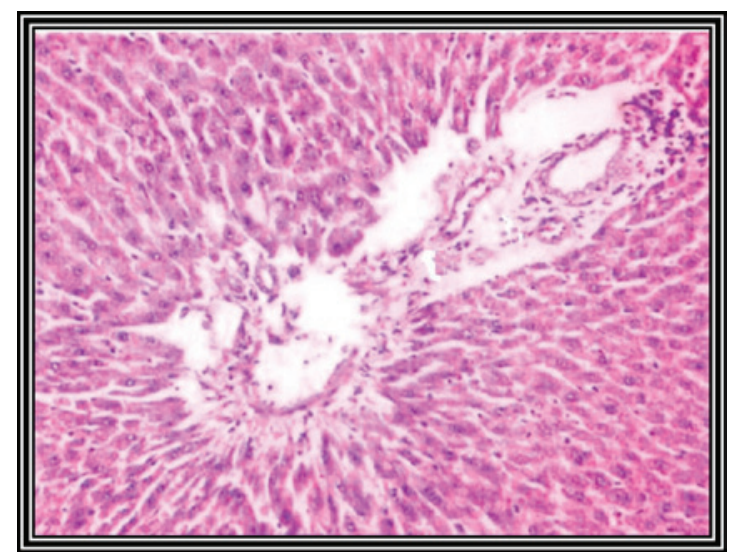

Figure 5. Photomicrograph of a liver section from rats pretreated with curcumin and taurine, followed by DENA injection twice a week for 8 weeks. Curcumin- and taurine-treated rats showed reactive hepatocytes, with condensed chromatin and small nuclei. Moderate amount of bile duct proliferation was observed. No malignant lesions were observed (hematoxylin and eosin staining; magnification, $\mathrm{x} 120$ ).

Liver tissue sections from the rats in the curcumin plus taurine group showed normal liver architecture, with well-preserved hepatocytes (Fig. 5). In addition, the architecture and morphology of the rat liver tissue section from the curcumin plus taurine group were similar to the control group. These results suggest that curcumin and taurine do not have toxic effects on the animal liver.

Electron microscope observations. In the normal control rats, the hepatocytes showed markedly swollen rough endoplasmic reticulum (RER), with few ribosomes attached to their cisternae (Fig. 6). The liver sections of the DENA-treated group showed degenerative cytoplasmic vacuolization, disrupted organelles and malignant changes of the nucleus. In addition, the mitochondria and ER cisternae appeared irregular, and infiltration of inflammatory cells, including macrophages and lymphocytes, were observed in the DENA-treated rat livers (Fig. 7).

In the curcumin-treated group, the number of damaged hepatocytes was unchanged, as compared with the 


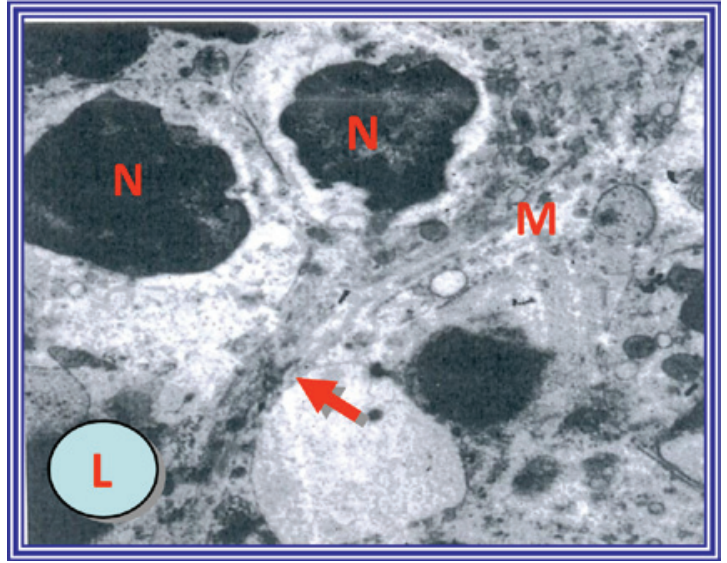

Figure 6. Electron micrograph of hepatocytes from control untreated rats showing the nucleus $(\mathrm{N})$ and cytoplasmic organelles, in particular irregular mitochondria (M). The desmosomal junction along the contact line between cell membranes (arrow). (L) Lipid droplets. Uranyl acetate and lead citrate staining; magnification, $\mathrm{x} 4,000$.

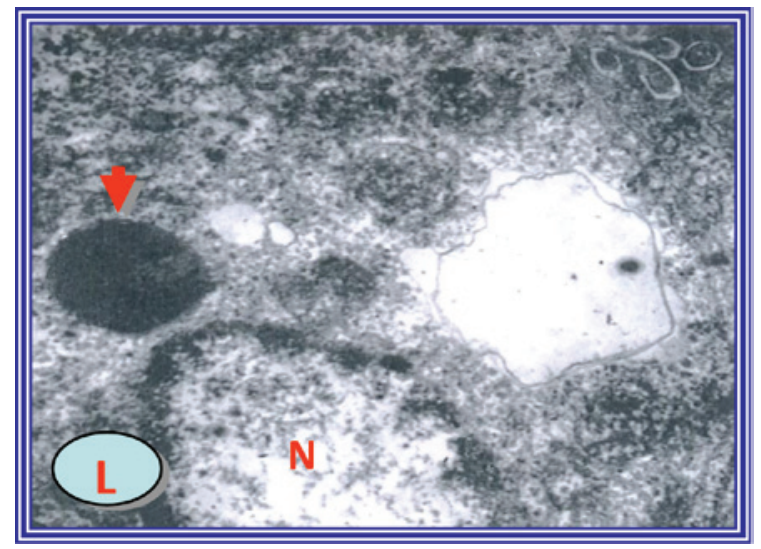

Figure 7. Electron micrograph of hepatocytes from diethylnitroseamine-injected rats showing degenerative cytoplasmic vacuolization, disrupted organelles and nuclear malignant changes. (N) Nucleus and (L) lipid droplet. Uranyl acetate and lead citrate staining; magnification, x4,000.

DENA-treated group, although the extent of their internal damage was decreased. Microvilli of the hepatocytes continued to project into the expanded intercellular spaces; however, recovery of the fine structures of the cellular organelles was evident (data not shown). In the DENA-injected group, hepatic necrosis and infiltration of inflammatory cells, particularly into the pericentral region, were observed. However, in the taurine-treated group, these biological changes were diminished and the development of hepatic fibrosis in the pericentral region was inhibited (data not shown).

In the curcumin- plus taurine-treated group, the hepatocytes appeared enlarged and pale, and some exhibited mitotic activity. Furthermore, these cells showed marked dilatation of the RER, indicating some loss of their ribosomes. The periorbital hepatocytes remained unaffected and appeared intact and almost normal. In addition, the nuclei, mitochondria and other organelles were more regular in the curcumin plus taurine group, as compared with the DENA-injected group (Fig. 8).

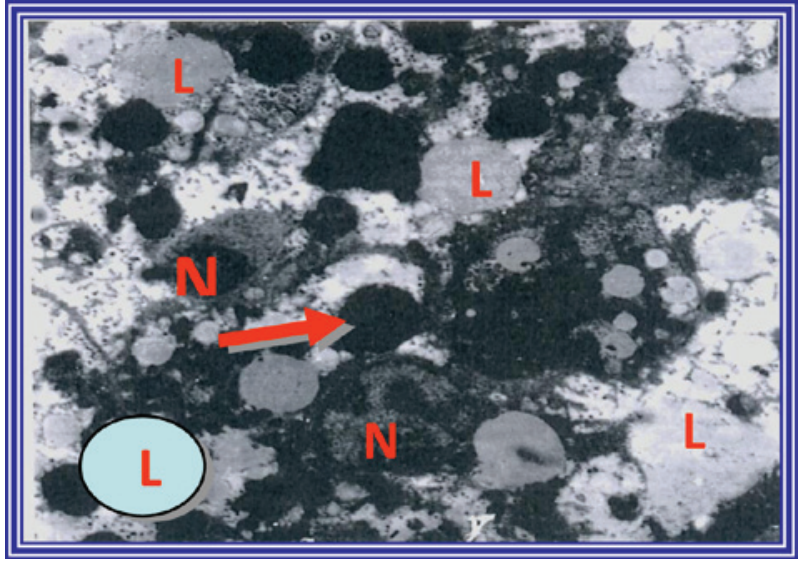

Figure 8. Electron micrograph of hepatocytes from curcumin- plus taurine-treated and diethylnitroseamine-injected rats showing the perinuclear zone of the liver containing reactive hepatocytes with condensed chromatin and small nucleoli (N). Preservation of the hepatocytes and reorganization of venous congestion in the central veins was observed. There was an increased number of lipid droplets (L), and pools of glycogen (arrow) were noticed in the absence of malignant changes (uranyl acetate and lead citrate staining, magnification, $\mathrm{x} 4,000)$

\section{Discussion}

The present study aimed to investigate the protective effects of taurine and curcumin, used alone or in combination, against hepatocarcinogenesis in a DENA-induced rat model of HCC. In the present study, serum levels of AFP and AFU were significantly elevated in the DENA-injected rats, which was consistent with the results of previous studies that demonstrated an association between AFP and AFU serum levels in rats with DENA-induced HCC $(43,44)$.

Conversely, the serum levels of AFP and AFU were significantly decreased in the curcumin-treated rats, thus suggesting a potential protective role of this natural agent against hepatocarcinogenesis. Previous studies have reported anti-inflammatory, antioxidant and anti-cancer activities for curcumin (45-49). The serum levels of AFP and AFU were similarly decreased in the taurine-treated rats, as compared with the DENA-injected rats. These results suggested that taurine may also have a protective effect against hepatocarcinogenesis. Taurine has previously been shown to attenuate or prevent hepatic damage (necrosis and fibrosis) induced by carbon tetrachloride (CCL4) (50-53). Furthermore, in the present study, the serum levels of AFP and AFU were significantly downregulated in the curcumin- plus taurine-treated group, as compared with the DENA-injected group.

The mechanism of action of these two natural compounds is based on the secretion of various cytokines that function via the following pathway: Stimulation of antitumor immune responses, followed by induction of tumor cell apoptosis, inhibition of the uncontrolled proliferation of cancer cells and suppression of angiogenesis $(54,55)$. In the present study, the serum levels of IL-2 and IFN- $\gamma$ were significantly decreased in the DENA-treated group, as compared with the control group. These results were consistent with a previous study, in which the production of various cytokines, including IL-2, IL-4, IL-5, IFN- $\gamma$ and TNF- $\alpha$, was shown to be suppressed in cancer patients (56). 
The present study demonstrated that the pathogenic alterations induced by DENA could be inhibited by curcumin treatment. This finding may have been due to the immunomodulatory effect of curcumin, since previous studies have reported that curcumin is a safe and useful immunomodulator (57-60). In the present study, the serum levels of IL-2 and IFN- $\gamma$ were significantly elevated in the taurine-treated group; thus suggesting that taurine may also exert an immunoregulatory role. This finding is consistent with a previous study, in which taurine was shown to alter the activity of the immune system to protect hepatocytes against membrane disintegration during rat hepatocarcinogenesis (61).

Potential immunoregulatory properties for taurine have been suggested, which are based on the modulation of key proinflammatory cells, in particular neutrophils and T lymphocytes (62). Furthermore, another study using a taurine derivative (taurine chloramines) demonstrated that taurine was able to regulate the synthesis of proinflammatory cytokines, thus suggesting that taurine may have a role in the initiation and propagation of the immune response (63). In addition, a previous study reported that the levels of IL-2 and IFN- $\gamma$ were markedly elevated following treatment with curcumin and taurine, and were approximately equal to the control untreated levels (64).

In the present study, a histopathological analysis of liver tissue sections from the DENA-treated group at 4 weeks following DENA injection showed mild dysplastic changes and inflammatory cell infiltration. At 6 weeks, the DENA-injected rat liver tissues showed dysplastic changes, including disorganized hepatic tissue. These results were consistent with a previous study, in which hepatocarcinogenesis was shown to be induced in rats at 6 weeks following injection with DENA and weekly subcutaneous injection of CCL4 (65). In the present study, DENA injection for 8 weeks resulted in malignant changes of the liver tissues, including disorganized and irregularly arranged hepatocytes. Furthermore, electron microscopy confirmed the histopathological changes and showed the presence of HCC in the DENA-treated group, as indicated by mitochondrial accumulation, RER stacks and nuclear malignant changes. These results were consistent with a previous study, which demonstrated that normal hepatocytes had fewer mitochondria as compared with HCC cells (66). In addition, HCC cells were shown to contain a greater abundance of, and more widely dispersed, RER.

The present study demonstrated that curcumin effectively inhibited DENA-induced hepatic damage in a rat model of HCC. A histopathological analysis showed moderate improvements in the hepatocellular structure of curcumin-treated rats, as well as the absence of nuclear changes and malignancy. However, some apoptotic changes, such as cell membrane lysis, were observed, which may have been due to the anti-cancer effect of curcumin. These results were in agreement with a previous study that reported direct anti-carcinogenic activities for curcumin (67). Similarly, previous studies demonstrated that curcumin was able to inhibit the proliferation of various cancer cells in culture and prevent carcinogenesis in rodents $(29,47,68)$. In the present study, electron microscopy detected numerous mitochondria, condensed chromatin, small nucleoli and stacks of RER in the hepatocytes of the curcumin-treated rats. These results were consistent with a previous study (69), in which numerous hallmarks of apoptosis, including DNA laddering, chromatin condensation, fragmentation and apoptosis, were observed in curcumin-treated human hepatoblastoma cells.

The present study demonstrated a protective effect for taurine against hepatic damage, as shown by the well-preserved hepatocytes in lung tissue sections from taurine-treated rats. This finding may be due to one or more of the biological roles that have previously been reported for taurine, including antioxidant (free radical scavenging), membrane stabilizing, and immune system potentiation activities (70). Furthermore, these results were supported by a previous study that reported that taurine was a powerful prophylactic agent against hepatocarcinogenesis in rats (71). The electron microscopic observations in the present study suggested that taurine preserves the morphology of major organelles in hepatocytes and delays the development of fibrosis, which was consistent with Tasci et al (72).

In the present study, combined treatment with curcumin and taurine prior to DENA injection resulted in well-preserved hepatocytes and reorganization of venous congestion in the central veins. These findings suggested that the combination of taurine and curcumin exerted a protective effect against hepatocarcinogenesis, which may be due to the anti-cancer activity of curcumin (29), and the anti-neoplastic effect of taurine and its derivatives via inhibition of cell proliferation, induction of tumor cell apoptosis and suppression of angiogenesis (73-77).

In conclusion, the present study demonstrated that combined use of curcumin and taurine exerted a protective effect against hepatocarcinogenesis in a rat model of DENA-induced HCC. Further studies should assess the efficacy of using curcumin and taurine as a potential prophylactic combination therapy against human hepatocarcinogenesis in high-risk groups that are exposed to chemical carcinogens or viral infections, such as hepatitis B or C.

\section{Acknowledgements}

The authors would like to thank Mr. Ahmed EL-Husseiny, a research assistant at the Department of Cancer Biology at the National Cancer Institute, Cairo University, for his efforts in supporting the publication of this work, and the staff at the animal care facility for their support in taking care of the animals during the experimental procedures.

\section{References}

1. Di Stefano G, Fiume L, Bolondi L, Lanza M, Pariali M and Chieco P: Enhanced uptake of lactosaminated human albumin by rat hepatocarcinomas: Implications for an improved chemotherapy of primary liver tumors. Liver Int 25: 854-860, 2005.

2. Jemal A, Bray F, Center MM, Ferlay J, Ward E and Forman D: Global cancer statistics. CA Cancer J Clin 61: 69-90, 2011

3. Mann CD, Neal CP, Garcea G, Manson MM, Dennison AR and Berry DP: Phytochemicals as potential chemopreventive and chemotherapeutic agents in hepatocarcinogenesis. Eur J Cancer Prev 18: 13-25, 2009.

4. Glauert HP, Calfee-Mason K, Stemm DN, Tharappel JC and Spear BT: Dietary antioxidants in the prevention of hepatocarcinogenesis: a review. Mol Nutr Food Res 54: 875-896, 2010. 
5. Lim DY, Jeong Y, Tyner AL and Park JH: Induction of cell cycle arrest and apoptosis in HT-29 human colon cancer cells by the dietary compound luteolin. Am J Physiol Gastrointest Liver Physiol 292: G66-G75, 2007.

6. Cheng YL, Chang WL, Lee SC, Liu YG, Chen CJ, Lin SZ, Tsai NM, Yu DS, Yen CY and Harn HJ: Acetone extract of Angelica sinensis inhibits proliferation of human cancer cells via inducing cell cycle arrest and apoptosis. Life Sci 75: 1579-1594, 2004.

7. Baliga MS, Meleth S and Katiyar SK: Growth inhibitory and antimetastatic effect of green tea polyphenols on metastasisspecific mouse mammary carcinoma 4T1 cells in vitro and in vivo systems. Clin Cancer Res 11: 1918-1927, 2005.

8. Michaud DS, Feskanich D, Rimm EB, Colditz GA, Speizer FE, Willett WC and Giovannucci E: Intake of specific carotenoids and risk of lung cancer in 2 prospective US cohorts. Am J Clin Nutr 72: 990-997, 2000

9. Kim ND, Mehta R, Yu W, Neeman I, Livney T, Amichay A, Poirier D, Nicholls P, Kirby A, Jiang W and Mansel R Chemopreventive and adjuvant therapeutic potential of pomegranate (Punica granatum) for human breast cancer. Breast Cancer Res Treat 71: 203-217, 2002.

10. Yang SF, Yang WE, Chang HR, Chu SC and Hsieh YS: Luteolin induces apoptosis in oral squamous cancer cells. J Dental Res 87: 401-406, 2008

11. Pistollato F, Giampieri F and Battino M: The use of plant-derived bioactive compounds to target cancer stem cells and modulate tumor microenvironment. Food Chem Toxicol 75: 58-70, 2015.

12. Schuller-Levis G, Mehta PD, Rudelli R and Sturman J: Immunologic consequences of taurine deficiency in cats. J Leukoc Biol 47: 321-331, 1990.

13. Lake N, Wright ED and Lapp WS: Effects of taurine deficiency on immune function in mice. Adv Exp Med Biol 315: 241-243, 1992.

14. Bustamante J, Lobo MV, Alonso FJ, Mukala NT, Giné E, Solís JM, Tamarit-Rodriguez J and Martín Del Río R: An osmotic-sensitive taurine pool is localized in rat pancreatic islet cells containing glucagon and somatostatin. Am J Physio Endocrinol Metab 281: E1275-E1285, 2001.

15. Miyazaki T, Karube M, Matsuzaki Y, Ikegami T, Doy M, Tanaka N and Bouscarel B: Taurine inhibits oxidative damage and prevents fibrosis in carbon tetrachloride-induced hepatic fibrosis. J Hepatol 43: 117-125, 2005

16. Tasci I, Mas MR, Vural SA, Deveci S, Comert B, Alcigir G, Mas N, Akay C, Bozdayi M, Yurdaydim C, et al: Pegylated interferon-alpha plus taurine in treatment of rat liver fibrosis. World J Gastroenterol 13: 3237, 2007.

17. Tasci I, Mas N, Mas MR, Tuncer M, Comert B: Ultrastructural changes in hepatocytes after taurine treatment in $\mathrm{CCl} 4$ induced liver injury. World J Gastroenterol 14: 4897, 2008.

18. Cetiner M, Sener G, Sehirli AO, Eksioğlu-Demiralp E, Ercan F, Sirvanci S, Gedik N, Akpulat S, Tecimer T and Yeğen BC: Taurine protects against methotrexate-induced toxicity and inhibits leukocyte death. Toxicol Appl Pharmacol 209: 39-50, 2005.

19. Alam SS, Hafiz NA and Abd El-Rahim AH: Protective role of taurine against genotoxic damage in mice treated with methotrexate and tamoxfine. Environ Toxicol Pharmacol 31: 143-152, 2011.

20. Akay C, Yaman H, Oztosun M, Cakir E, Yildirim AO, Eyi YE, Agilli M, Akgul EO, Aydin I, Kaldirim U, et al: The protective effects of taurine on experimental acute pancreatitis in a rat model. Hum Exp Toxicol 32: 522-529, 2013.

21. Tu S, Zhang X, Luo D, Liu Z, Yang X, Wan H, Yu L, Li H and Wan F: Effect of taurine on the proliferation and apoptosis of human hepatocellular carcinoma HepG2 cells. Exp Ther Med 10 193-200, 2015

22. Zhang X, Tu S, Wang Y, Xu B and Wan F: Mechanism of taurine-induced apoptosis in human colon cancer cells. Acta Biochim Biophys Sin (Shanghai) 46: 261-272, 2014.

23. Tu S, Zhang X, Luo D, Liu Z, Yang X, Wan H, Yu L, Li H and Wan F: Effect of taurine on the proliferation and apoptosis of human hepatocellular carcinoma HepG2 cells. Exp Ther Med 10: 193-200, 2015

24. Punithavathi D, Venkatesan $\mathrm{N}$ and Babu M: Curcumin inhibition of bleomycin-induced pulmonary fibrosis in rats. $\mathrm{Br}$ J Pharmacol 131: 169-172, 2000.

25. Kim KA, Lee WJ, Lim HK, Park CM, Park CK, Cha IH and Seol HY: Small hepatocellular carcinoma: Ultrasonographic findings and histopathologic correlation. Clin Imaging 27: $340-345,2003$
26. Duvoix A, Blasius R, Delhalle S, Schnekenburger M, Morceau F, Henry E, Dicato M and Diederich M: Chemopreventive and therapeutic effects of curcumin. Cancer Lett 223: 181-190, 2005.

27. Gulcubuk A, Altunatmaz K, Sonmez K, Haktanir-Yatkin D, Uzun H, Gurel A and Aydin S: Effects of curcumin on tumour necrosis factor-alpha and interleukin- 6 in the late phase of experimental acute pancreatitis. J Vet Med A Physiol Pathol Clin Med 53: 49-54, 2006.

28. Chuang SE, Kuo ML, Hsu CH, Chen CR, Lin JK, Lai GM, Hsieh CY and Cheng AL: Curcumin-containing diet inhibits diethylnitrosamine-induced murine hepatocarcinogenesis. Carcinogenesis 21: 331-335, 2000.

29. Huang MT, Newmark HL and Frenkel K: Inhibitory effects of curcumin on tumorigenesis in mice. J Cell Biochem Suppl 27: 26-34, 1997.

30. Subramanian M, Sreejayan, Rao MN, Devasagayam TP and Singh BB: Diminution of singlet oxygen-induced DNA damage by curcmin and related antioxidants. Mutat Res 311: 249-255, 1994.

31. Parshad R, Sanford KK, Price FM, Steele VE, Tarone RE, Kelloff GJ and Boone CW: Protective action of plant polyphenols on radiation-induced chromatid breaks in cultured human cells. Anticancer Res 18: 3263-3266, 1998

32. SamahaHS,KelloffGJ,Steele V,RaoCV and Reddy BS: Modulation of apoptosis by sulindac, curcumin, phenylethyl-3-methylcaffeate, and 6-phenylhexyl isothiocyanate: Apoptotic index as a biomarker in colon cancer chemoprevention and promotion. Cancer Res 57: 1301-1305, 1997.

33. Sikora E, Bielak-Zmijewska A, Piwocka K, Skierski J and Radziszewska E: Inhibition of proliferation and apoptosis of human and rat $\mathrm{T}$ lymphocytes by curcumin, a curry pigment. Biochem Pharmacol 54: 899-907, 1997.

34. Chen HW and Huang HC: Effect of curcumin on cell cycle progression and apoptosis in vascular smooth muscle cells. $\mathrm{Br}$ J Pharmacol 124: 1029-1040, 1998.

35. Jee SH, Shen SC, Tseng CR, Chiu HC and Kuo ML: Curcumin induces a p53-dependent apoptosis in human basal cell carcinoma cells. J Invest Dermatol 111: 656-661, 1998.

36. Jagetia GC and Aggarwal BB: "Spicing up" of the immune system by curcumin. J Clin Immunol 27: 19-35, 2007.

37. Bruck R, Ashkenazi M, Weiss S, Goldiner I, Shapiro H, Aeed H, Genina O, Helpern Z and Pines M: Prevention of liver cirrhosis in rats by curcumin. Liver Int 27: 373-383, 2007.

38. El-Houseini ME, Refaei MO, Amin AI and Abol-Ftouh MA: Potential role of curcumin and taurine combination therapy on human myeloid leukemic cells propagated in vitro. Leuk Lymphoma 54: 2281-2287, 2013.

39. Abdeen SH, El-Houseini ME, El-Sherbiny M, Tabashy R and Salah A: Ex vivo assessment of the protective effect of curcumin and taurine against human hepatocarcinogenesis. J Basic Appl Zool 66: 180-187, 2013

40. Leventhal, Ruth and Russell F Cheadle: Medical parasitology: A Self-Instructional Text. FA Davis, 2011.

41. El-Houseini, ME, El-Sherbiny M, ME, Awad, El-Din Awad M, AmerMA, El Din AH and Hussein TD: Serum alpha-L-fucosidase enzyme activity as a marker for hepatocellular carcinoma: Comparison with AFP using ROC analysis. J Egypt Natl Cancer Inst 13: 227-283, 2001

42. Bravman JC and Sinclair R: The preparation of cross-section specimens for transmission electron microscopy. J Electron Microsc Tech 1: 53-61, 1984.

43. Liu Y, Daley S, Evdokimova VN, Zdobinski DD, Potter DM and Butterfield LH: Hierarchy of alpha fetoprotein (AFP)-specific $\mathrm{T}$ cell responses in subjects with AFP-positive hepatocellular cancer. J Immunol 177: 712-721, 2006.

44. Butterfield LH, Ribas A, Potter DM and Economou JS: Spontaneous and vaccine induced AFP-specific T cell phenotypes in subjects with AFP-positive hepatocellular cancer. Cancer Immunol Immunother 56: 1931-1943, 2007.

45. Guo LY, Cai XF, Lee JJ, Kang SS, Shin EM, Zhou HY, Jung JW and Kim YS: Comparison of suppressive effects of demethoxycurcumin and bisdemethoxycurcumin on expressions of inflammatory mediators in vitro and in vivo. Arch Pharm Res 31: 490-496, 2008.

46. Sandur SK, Pandey MK, Sung B, Ahn KS, Murakami A, Sethi G, Limtrakul P, Badmaev V and Aggarwal BB: Curcumin, demethoxycurcumin, bisdemethoxycurcumin, tetrahydrocurcumin and turmerones differentially regulate anti-inflammatory and anti-proliferative responses through a ROS-independent mechanism. Carcinogenesis 28: 1765-1773, 2007. 
47. Suryanarayana P, Satyanarayana A, Balakrishna N, Kumar PU and Reddy GB: Effect of turmeric and curcumin on oxidative stress and antioxidant enzymes in streptozotocin-induced diabetic rat. Med Sci Monit 13: BR286-BR292, 2007.

48. Kunnumakkara AB, Diagaradjane P, Guha S, Deorukhkar A, Shentu S, Aggarwal BB and Krishnan S: Curcumin Sensitizes human colorectal cancer xenografts in nude mice to gamma-radiation by targeting nuclear factor-kappaB-regulated gene products. Clin Cancer Res 14: 2128-2136, 2008.

49. Lin J and Chen A: Activation of peroxisome proliferator-activated receptor-gamma by curcumin blocks the signaling pathways for PDGF and EGF in hepatic stellate cells. Lab Invest 88: 529-540, 2008.

50. Waterfield CJ, Turton JA, Scales MD and Timbrell JA: Taurine, a possible urinary marker of liver damage: A study of taurine excretion in carbon tetrachloride-treated rats. Arch Toxicol 65: 548-555, 1991.

51. Chen Y, Li S and Zhang X: Taurine inhibits deposition of extracellular matrix in experimental liver fibrosis in rats. Zhong Hua Gan Zang Bing Za Zhi 7: 165-167, 1999 (In Chinese).

52. Wu QD, Wang JH, Fennessy F, Redmond HP and Bouchier-Hayes D: Taurine prevents high-glucose-induced human vascular endothelial cell apoptosis. Am J Physiol 277: C1229-C1238, 1999.

53. Dinçer S, Ozenirler S, OzE, Akyol G and Ozoğul C: The protective effect of taurine pretreatment on carbon tetrachloride-induced hepatic damage-a light and electron microscopic study. Amino Acids 22: 417-426, 2002

54. Boujendar S, Arany E, Hill D, Remacle C and Reusens B: Taurine supplementation of a low protein diet fed to rat dams normalizes the vascularization of the fetal endocrine pancreas. J Nutr 133 : 2820-2825, 2003 .

55. Yoysungnoen $\mathrm{P}$, Wirachwong $\mathrm{P}$, Bhattarakosol $\mathrm{P}$, Niimi $\mathrm{H}$ and Patumraj S: Effects of curcumin on tumor angiogenesis and biomarkers, COX-2 and VEGF, in hepatocellular carcinoma cell-implanted nude mice. Clinical Hemorheol Microcirc: 109-115, 2006

56. Tomova R, Pomakov J, Jacobs JJ, Adjarov D, Popova S, Altankova I, Den Otter W and Krastev Z: Changes in cytokine profile during local IL-2 therapy in cancer patients. Anticancer Res 26: 2037-2047, 2006.

57. Antony S, Kuttan R and Kuttan G: Immunomodulatory activity of curcumin. Immunol Invest 28: 291-303, 1999.

58. Jagetia GC and Aggarwal BB: 'Spicing up' of the immune system by curcumin. J Clin Immunol 27: 19-35, 2007.

59. Yadav VS, Mishra KP, Singh DP, Mehrotra S and Singh VK: Immunomodulatory effects of curcumin. Immunopharmacol Immunotoxicol 27: 485-497, 2005.

60. Aggarwal BB, Surh YJ and Shishodia S (eds). The Molecular Targets and Therapeutic Uses of Curcumin in Health and Disease. Springer Science+Business Media, 2007.

61. You JS and Chang KJ: Taurine protects the liver against lipid peroxidation and membrane disintegration during rat hepatocarcinogenesis. Adv Exp Med Biol 442: 105-112, 1998.

62. Redmond HP, Stapleton PP, Neary P and Bouchier-Hayes D: Immunonutrition: The role of taurine. Nutrition 14: 599-604, 1998
63. Kim H, Jeon H, Kong H, Yang Y, Choi B, Kim YM, Neckers L and Jung Y: A molecular mechanism for the anti-inflammatory effect of taurine-conjugated 5-aminosalicylic acid in inflamed colon. Mol Pharmacol 69: 1405-1412, 2006.

64. Chorazy M, Kontny E, Marcinkiewicz J and Maśliński W: Taurine chloramine modulates cytokine production by human peripheral blood mononuclear cells. Amino Acids 23: 407-413, 2002.

65. Abdel aziz MT, El Asmar MF, Atta HM, Mahfouz S, Fouad HH, Roshdy NK, Rashed LA, Sabry D, Hassouna AA and Taha FM: Efficacy of mesenchymal stem cells in suppression of hepatocarcinorigenesis in rats: Possible role of Wnt signaling. J Exp Clin Cancer Res 30: 49, 2011.

66. Couch JA: Light and electron microscopic comparisons of normal hepatocytes and neoplastic hepatocytes of well-differentiated hepatocellular carcinomas in a teleost fish. Dis Aquat Org 16: 1-14, 1993.

67. Aggarwal S, Ichikawa H, Takada Y, Sandur SK, Shishodia S and Aggarwal BB: Curcumin (diferuloylmethane) down-regulates expression of cell proliferation and antiapoptotic and metastatic gene products through suppression of IkappaBalpha kinase and Akt activation. Mol Pharmacol 69: 195-206, 2006.

68. He SM, Li CG, Liu JP, Chan E, Duan W and Zhou SF: Disposition pathways and pharmacokinetics of herbal medicines in humans. Curr Med Chem 17: 4072-4113, 2010.

69. Aggarwal BB, Kumar A and Bharti AC: Anticancer potential of curcumin: Preclinical and clinical studies. Anticancer Res 23: 363-398, 2003.

70. Koyama I, Nakamura T, Ogasawara M, Nemoto M and Yoshida T: The protective effect of taurine on the biomembrane against damage produced by the oxygen radical. Adv Exp Med Biol 315: 355-359, 1992.

71. El-Agamy DS: Comparative effects of curcumin and resveratrol on aflatoxin $\mathrm{B}(1)$-induced liver injury in rats. Arch Toxicol 84: 389-396, 2010.

72. Tasci I, Mas N, Mas MR, Tuncer M and Comert B: Ultrastructural changes in hepatocytes after taurine treatment in CCl4 induced liver injury. World J Gastroenterol 14: 4897-4902, 2008.

73. McCourt M, Wang JH, Sookhai S and Redmond HP: Taurolidine inhibits tumor cell growth in vitro and in vivo. Ann Surg Oncol 7: 685-691, 2000

74. Calabresi P, Goulette FA and Darnowski JW: Taurolidine: Cytotoxic and mechanistic evaluation of a novel antineoplastic agent. Cancer Res 61: 6816-6821, 2001.

75. Stendel R, Stoltenburg-Didinger G, Al Keikh CL, Wattrodt M and Brock M: The effect of taurolidine on brain tumor cells. Anticancer Res 22: 809-814, 2002.

76. Petrovic L, Schlegel KA, Ries J, Park J, Diebel E, Schultze-Mosgau S and Wiltfang J: In vitro effect of taurolidine on squamous cell carcinoma in the oral cavity. Mund Kiefer Gesichtschir 7: 102-107, 2003 (In German).

77. Rodak R, Kubota H, Ishihara H, Eugster HP, Könü D, Möhler H, Yonekawa $\mathrm{Y}$ and Frei K: Induction of reactive oxygen intermediates-dependent programmed cell death in human malignant ex vivo glioma cells and inhibition of the vascular endothelial growth factor production by taurolidine. J Neurosurg 102: 1055-1068, 2005. 